OPEN ACCESS

ISSN 2548-3501 (online)

Edited by:

Eny Maryanti

Reviewed by:

Rahmawati

${ }^{*}$ Correspondence:

Tariq Tawfeeq Yousif Alabdullah

tariqtariq1984@gmail.com

Received: 10 June 2019

Accepted: 12 July 2019

Published: 31 July 2019

Citation:

TTYA, ERA and MM (2019) Effect of

Board Size and Duality on

Corporate Social Responsibility:

What has Improved in Corporate

Governance in Asia?

Journal of Accounting Science. 3:2.

doi: 10.21070/jas.v3i2.2810

\section{Effect of Board Size and Duality on Corporate Social Responsibility: What has Improved in Corporate Governance in Asia?}

\author{
Tariq Tawfeeq Yousif Alabdullah ${ }^{1 *}$, Essia Ries Ahmed ${ }^{2}$, Mohammed Muneerali $^{3}$ \\ ${ }^{1}$ Accounting Department, College of Administration and Economics, University of Basrah, Iraq, ${ }^{2}$ Collage of Economics, \\ Management and Information Systems, University of Nizwa, Oman, ${ }^{3}$ Collage of Economics, Management and Information \\ Systems, University of Nizwa, Oman
}

The aim of this study is to examine the relationship between board size and CEO duality, and corporate social responsibility (CSR). A total of 91 public listed companies from Bursa Malaysia representing the sample of the current study were selected. Secondary data were used and sourced from annual report on the companies. Using descriptive statistics, the existence and the extent of CSR disclosure on Malaysian companies were ascertained. An analysis of the quantitative data was then made using the Partial Least Squares (PLS). The findings from this research show that the role of board size suggest a significant and positive relationship with CSR disclosure. On the other hand, CEO duality on CSR disclosure indicates a negative relationship. This research contributes to the existing literature in terms of the roles of board Size and CEO duality on CSR initiatives. Furthermore, It highlights the necessity of following the new trends in corporate governance field by investigating its mechanisms with the new trendsin financial Industry from Islamic perspective as this might be positively added to the field of corporate governance due to the high significant role for these two fields.

Keywords: Corporate governance, CEO duality, Board size, CSR, Asia

Penelitian ini menguji hubungan antara ukuran dewan (komisaris) dan dualitas CEO, serta tanggung jawab sosial perusahaan (CSR). Sampel yang diambil untuk penelitian ini adalah 91 perusahaan publik dari Bursa Malaysia. Data sekunder yang digunakan bersumber dari laporan tahunan perusahaan. Untuk memastikan pengungkapan CSR pada perusahaan Malaysia, peneliti menggunakan metode statistik deskriptif. Analisis data kuantitatif dilakukan dengan menggunakan Partial Least Squares (PLS). Hasil dari penelitian ini menunjukkan bahwa ukuran dewan komisaris memiliki hubungan yang signifikan dan positif dengan pengungkapan CSR. Di sisi lain, dualitas CEO memiliki hubungan negatif dengan pengungkapan CSR. Penelitian ini berkontribusi pada literatur yang sudah ada terkait dengan peran ukuran dewan komisaris dan dualitas CEO pada pelaksanaan CSR. Selain itu, penelitian ini juga menyoroti perlunya mengikuti tren baru dalam bidang corporate governance (tata kelola perusahaan) dengan menyelidiki mekanismenya dengan tren baru dalam industri keuangan dari perspektif Islam karena hal ini dapat ditambahkan secara positif ke dalam bidang tata kelola perusahaan karena signifikan peran yang tinggi dari kedua bidang tersebut. 


\section{INTRODUCTION}

Countries in both developed and developing economies put more attention on dealing with corporate governance in their corporations Abushammala et al. (2015). The reason behind that is that CG has played essential role in operating and controlling the framework of the organizations (Alabdullah et al. (2016); Alabdullah (2018a); Alfadhl and Alabdullah (2013). This system increases the interest of the shareholders via relying on set of robust mechanisms and principles of corporate governance to control the actions of the companies based on principles of disclosure and transparency. Corporate governance has received attention because it positively affects the performance and value of the company (Alabdullah et al. (2016); Alabdullah et al. (2014b); Alfadhl and Alabdullah (2013) because applying such a system has its positive impact on market growth and economic growth (Abushammala et al. (2015), Alabdullah (2016)). CG can be utilized as a building block for the firms to maximize their value by creating a competitive advantage, enabling their performance to be enhanced and thereby leading to an overall improvement in a country's economy (Alabdullah (2016a); Alabdullah (2016b). Larger board size has a positive impact on firm performance with its two measurements: Return on Assets (ROA) and Return on Equqity (ROE), (Alabdullah et al. (2018) ; Alabdullah (2016c) CG is a source of much interest worldwide as it is a useful tool to reduce or mitigate any business crises on the one hand, and on the other CG can be utilized as a building block for the firms to maximize their value by creating a competitive advantage, enabling their performance to be enhanced and thereby leading to an overall improvement in a country's economy Alabdullah (2016d) . It is recommended that corporate entities should promote corporate governance to send a positive signal to potential investors. The Central Bank of Kenya (CBK) should continue enforcing and encouraging firms to adhere to good corporate governance for financial institutions for efficiency and effectiveness and regulatory agencies including the government should promote and socialise corporate governance and its relationship to firm performance across industries (Alabdullah et al. (2018); Mang'unyi (2011). Adopting one corporate governance proposal increases shareholder value by $2.8 \%$. The market reaction is larger in firms with more antitakeover provisions, higher institutional ownership, and stronger investor activism for proposals sponsored by institutions (Cuñat et al. (2012) . There is no comprehensive, "one size fits all" global corporate governance or CSR system, based on western codes and regulations that can be implemented in emerging markets (Lenssen et al. (2011)). Stronger governance mechanisms would reduce opportunistic management behavior, thus improving the quality and reliability of earning management (Gulzar (2011). It indicates that larger and improved boards are associated with a greater depth of intellectual knowledge, which in turn helps in improving decision-making and enhancing the performance (Arora and C.Sharma (2016) . Good corporate governance is imperative to all organizations and must be encouraged for the interest of all stakeholders (Alabdullah (2018a)

Corporate governance is manifested through various dimensions. These include code of corporate governance, board independence, skills, size, committees experience and board diversity (Dewji and Miller (2013); Narwal and Jindal (2015)). Banks with strong corporate governance practices had substantially higher stock returns in the aftermath of the market meltdown, indicating that good governance may have mitigated the adverse influence of the crisis on bank credibility (Peni and Vähämaa (2012)). The motivation factor of corporate governance is evidenced especially in non-financial companies. Whilst financial companies cited that their EnterpriseWide Risk Management (EWRM) practices were not only being driven by corporate governance compliance, but also for good business practice and improved decision making. In addition the motives of its implementation ensured the survival of the company and value creation (Alabdullah et al. (2016); Manab et al. (2010); Alabdullah and Ahmed (2018)). Another study they found that more socially responsible firms enjoy more favorable credit ratings. In particular, an increase in Corporate Social Responsibility (CSR) by one standard deviation improves the firm's credit rating by as much as $4.5 \%$ (Jiraporn et al. (2014)). Enterprises must focus on productive 
stakes in the global economy, and include social responsibility "which creates long-term sustainability for corporate success by meeting the needs of all suppliers, investors and employees" into their ownership advantage. The perspective and implementation of CSR has important consequences for Multinational Enterprises through FDI in fostering development (Tai and Chuang (2014)). Firms should continue to adopt corporate governance for ethical reasons to meet stakeholder's social and environmental needs for sustainable development (I.Dzingai and Fakoya (2017). It has mentioned that the board independence and meeting frequency moderate the relationship between return on equity and return on assets by enhancing board characteristics and the firms' performance indicators measures among corporate governance mechanisms (Palaniappan (2017) . Turkey Corporate Governance Index (TCGI) predicts higher market value (with firm fixed effects) and higher firm-level profitability with firm random effects. The principal subindex which predicts higher market value and profitability, and drives the results for TCGI as a whole, is disclosure subindex and also found that the determinants of firms' governance and its most firm-specific factors have little effect on firms' governance choices (Ararat et al. (2017)). With rising stakeholder concerns over sustainable development, corporate social responsibility (CSR) has become key for the business community, moving the business model beyond financial performance to a new voluntary paradigm based on natural resource conservation, social welfare, stakeholder engagement and economic performance (Aitsidhoum and Serra (2018) ; Alabdullah et al. (2014c). Improved corporate governance has leads investors more optimistic and have more trust in Seasoned Equity Offering (SEO) issuers when they believe they are better protected (Chen (2017). Social expectations had the greatest impact on both stakeholder pressure and green practice adoption. Moreover, they found that the higher the job titles were, the more willing they were to adopt green practices and it indicated that the current top management of Korean logistics companies is well aware of being mandated to make a commitment to corporate environmental responsibility and green practices (Lee et al. (2018)).

Recently, regulatory in several countries have demonstrated their needs for new corporate governance (CG) to enhance the transparency in corporations. In Asia, the financial crisis led to shed light to the need for more evidence and events on the issues of CG and transparency. Especially the increasing of corruption situations (Ahmed et al. (2019); Alabdullah (2018b) ; Alabdullah (2016); Alabdullah et al. (2014a); Alfadhl and Alabdullah (2013); Abushammala et al. (2015).

Ehikioya (2009) mentioned that recent financial disturbance in Asia in the late 1990s with several scandals in Enron, World Com and other related firms has again encouraged investors, policy makers, and other stakeholders to take interest towards good CG. In Asian countries such as Jordan. For instance, Alabdullah et al. (2018) discussed the relation of non-executive directors; and the board of directors' size, and growth/capital structure in a sample of 100 firms that was made available by nonfinancial sector in Jordan. The results showed that increasing the number of non-executive directors in the board, in another meaning increasing size of the board has a negative and significant effect on capital structure.

Researchers classify three key roles; resource dependence and control. In Asia, the role of resource dependence such as board of directors members offers information to top management and resources is clearer than other two roles. It is important because it shows that top management might choose board members in order to develop the companies rather than focusing on controlling and monitoring the management (Fan (2004). Unlike many recent studies that focused on financial companies, the current study discusses corporate governance' studies that applies in companies belong to non-financial listed companies in some countries in the developing markets. With regard to studies done in Asia, Fan and Wong (2001) recommended that Big 5 auditors in Asia have a role of corporate governance and they are likely to focus on transparency in companies' financial statements and reports as they have a better reputation to uphold; might be more independent than local companies; concentrate larger legal liability for making errors, and they probably perceived disclosure quality because of their recognizable and prominent names.

Based on the literature that have been done in Asia, it is clearly appeared that there is still no improvement in the field of corporate governance. Alternatively, new trends in the business 
world have been given an concentrated consideration to the financial Industry from Islamic perspective due to the financial crises and drawbacks as an substitute option through using instruments based on the real economic (Ahmed et al. (2014a); Ahmed et al. (2016); Ahmed et al. (2018a) ; Ahmed et al. (2014b) ; Ahmed et al. (2014c) ; Ahmed et al. (2019) ; Ahmed (2010)), and this provides more concentration to the risk management in the instruments of Islamic financial (Ahmed et al. (2019); Ahmed et al. (2018b); Ahmed et al. (2015); Ahmed et al. (2014c) Ahmed et al. (2015), Ahmed et al. (2013a); Ahmed et al. (2012); Ahmed and Zuqibeh (2013) Ahmed and Zuqibeh (2013); Ahmed et al. (2013b) . Other studies in the same line also take in their account the moderating role shariah supervisory board from the perspective of Sukuk documentation and legitimacy as the study done by Ahmed et al. (2018b) and also previous studies like Ahmed et al. (2018c) dealt with the moderating role of Shariah supervisory board in its effect on sukuk pricing benchmark. This new and important trend should be tested and considered by the future studies.

Board of directors is one of the important essentials of corporate governance tool in management to ensure the company's business is being properly managed by their agents.Past studies suggested that board size effects will increased communication and coordination problems, decreased ability of the board to control management and the spread among a larger group of the cost of poor decision making (Lipton and lorsch (1992). Besides that Jizi et al. (2014) explained firms with larger boards are likely to disclose more CSR related information. The results indicate that, possibly because banks are complex organizations, having a larger number of directors share the work has a positive impact on the firm's attitude towards its stakeholders.

The relationship of CEO duality and level of CSR disclosure were studied by prior researchers. Some of the studies concluded there is no relationship between CEO duality and CSR disclosure (Cheng and Courtenay (2006); Fan and Wong (2001). However, Gul and Leung (2004) reported negative and significant relationship between CEO duality and the level of CSR disclosure. According to them when the CEO was holding chairman position the CSR disclosure was lower compared with company which had no CEO duality issue.

Prior studies presented positive relationship with board size and various type of CSR disclosure. M.Halme and .Huse (1997) and Rao et al. (2012) Rao et al. (2012) analyzed and concluded positive relationship of board size and environmental disclosure. Cheng and Courtenay (2006), Akhtaruddin et al. (2009) indicated board size has positive relation with voluntary corporate disclosure. Said et al. (2009) shows that positive relationship between board size and CSR disclosure index. Hence, it is hypothesized that:

H1: Board size positively associates with CSR.

Separating the positions of CEO and Chairman of the board possibly encouraged to enhance the observation of the board director's activities (Jensen (1993)). Companies with CEO and also holding chairman spot have greater chances to be related to the minor levels of quality of CSR disclosure. This is because the board is less motivated to monitor the companies transparency might be used to conceal frau and incompetence.

According to Forker (1992) and Gul and Leung (2004), CEO duality reduces overall accountability, making the companies less transparent for all relevant stakeholders. Yuen et al. (2008) whom researched on the influence of ownership features, corporate governance mechanism and firm specific features on the CSR disclosure of randomly selected 200 public listed companies in China and found a negative relationship between CEO duality and the extent of disclosures. This is supported by empirical studies such as Uwalomwa and Ajibolade (2013) ; Michelon and Parbonetti (2012)

Hence, it is hypothesized that:

$\mathrm{H} 2$ : CEO duality is negatively impacts CSR

\section{METHOD}

This study used quantitative approach,the sample size consists of 125 companies from trading and service, construction and properties industry that listed on Main Market of Bursa Malaysia. Content analysis was used to gather data from annual report 2018. Statistical tools such as 
SmartPLS version 3.0 and SPSS were used to analyze the collected data.

CSR : When a firm disclosed items related to CSR in annual report the firm will be given scored ' 1 ' while firm failed to disclose will be given ' 0 ' score. This scoring approach is chooses due to the simplicity and less controversial as it lessen the possible scoring bias and scaling issues in measuring the score (Haniffa and Cooke (2005). The total scores that a company can be achieved are 26 based on the listed checklist items.

The measurement for board size and CEO duality used in this study showTable 1 This information was collected from the annual report of the firm.

[Table 1 about here.]

\section{RESULT AND DISCUSSION}

The total sample used in this study is 125 firms from three main industries namely trading and services, properties and construction. Table 2 showed the composition of sample. The 125 firms choose randomly from overall population 352 inclusive trading and service, construction and property industry. Samples 45 taken from trading and services, 34 from construction and 46 from property. Frequency analysis of 125 samples is conducted by using the latest version of SPSS software. Frequency analysis measures the validity of sample and to check whether any missing sample for each variable.

[Table 2 about here.]

Table 3 explains the frequency analysis of board size in the companies. The least board size is 4 and 3 companies out of 125 had this size. The highest frequency is $20 \%$ which carries 8 directors in the board and most firms have this size. This was followed by 7 directors in the board which carried about $18.4 \%$. Only 1 firm had the 12 director size which carried $0.8 \%$.

[Table 3 about here.]

Besides board size, this study also analyzes the CEO duality. Table 4 explains only 9 companies out of 125 had CEO duality in the board of directors. It was equaled to $7.2 \%$ in total sample.

[Table 4 about here.]

Structural Model Path Coefficient

The path coefficient is significant when the t-value is more than critical value. Computed PLS structural model can be seen in Table 5 showed the path coefficient and R2 after run the PLS algorithm.

[Table 5 about here.]

${ }^{* *} \mathrm{p}<0.01,{ }^{*} \mathrm{p}<0.05$

Table 5 abridged the path coefficient, standard deviation and $\mathrm{t}$-value for each independent variable to dependent variable relationship. $\mathrm{H} 1$ analyze board size have positive relationship with CSR Disclosure. This explains the larger board size will disclose high CSR activities. The result for $\mathrm{H} 1$ indicates, it is statistically significant (path coefficient $=0.148$, $\mathrm{t}$-value $=1.667$ ), thus $\mathrm{H} 1$ accepted.

Hypothesis $\mathrm{H} 2$ proposed that CEO duality have negative relationship with CSR disclosure. The result not supported $\mathrm{H} 2$ which statically significant at $\mathrm{p}<0.05$ and negatively related (path coefficient $=-0.110$, $\mathrm{t}$-value $=1.351$ ), thus $\mathrm{H} 2$ was rejected. 


\section{IMPACT THE BOARD SIZE ON CSR}

Board size was obtained by measuring the total number of directors in the board. Zahra and Pearce (1989) explained when the board size is large it will reduce CEO ability to dominate the board of directors. Besides that large board size also will increase the transparency in monitoring top management choices and engagements (Mak and Roush (2000). Prior researchers have found positive and significant relationship between board size and CSR disclosure in Malaysia (Akhtaruddin et al. (2009); Said et al. (2009)

The findings of this study in align with previous researches. H1 projected large board size will endorse high level of CSR disclosure. The outcome from this study discover that board size do effect the relationship with CSR disclosure as the results is significant. This result similar with previous studies by Sadou et al. (2017) which the author studied on CSR disclosure on larger companies. The purpose of the study was to test on the enhancement in the range and quality of CSR disclosure in Malaysia. Sadou et al. (2017) concludes that companies with larger board size disclosed expressively more CSR facts. On the other Akbas (2016) studied on the relationship between board characteristics and environmental disclosure by examining 62 nonfinancial Turkish firms. The author also found statistically significant and positive relationship between board size and environmental disclosure. This can be further justify by analysis the sample, for example the highest board size 15 in the sample was obtained by Malaysia Airports Holdings Berhad and they scored total 16 scores out of total 25 scores in CSR disclosure. Most of the companies that score in between 15- 23 out of total 25 scores have bigger board size in range of 8-15 directors. As overall, the findings showed there is significantly positive relationship between board size and CSR disclosure. The bigger the board size of the company, the more CSR disclosure the company will disclosure.

\section{Impactthe CEO Duality on CSR}

CEO duality happens when the CEO of the company holds chairman position as well in the board of directors. Jensen and Meckling (1976) proposed when there is CEO duality in the board it has weaker observation from the board. Some previous revisions identified negative association of CEO duality and CSR disclosure ( Gul and Leung (2004)). H2 suggested that CEO duality has significant relationship with disclosure of CSR. The findings has negative and insignificant relationship with CSR disclosure. This is in align with research by Majumder et al. (2017). The research study about the relationship between corporate governance and corporate social disclosure and find insignificant negative association with CSR disclosure. In addition the findings also supporting the study of Ahmad et al. (2017) which discuss about the impact of CEO duality in corporate social reporting. The findings support there is negative nonsignificant relationship between CEO duality and CSR reporting. Based on the sample size 125, only 9 companies have the duality which indicates a very low duality rate in Malaysia under trading and services, construction and properties industry. This also supports the fact that majority of Malaysian firms complied with the suggestion of Malaysian Code of Corporate Governance (2012) where company should have a clear and separate role of chairman and CEO.

When the CEO in the board composition they tend to be more cautious to disclose CSR information. They might only report positive activities and out guard negative news to protect management reputation and capability. Besides that they avoid to disclose any negative news referring CSR to protect shareholders engagement. In this case the CSR disclosure will be lower because $\mathrm{CEO}$ dominance can impact the board decision. However as overall, the finding resulted CEO duality have negative impact and statistically non-significant to CSR .

\section{CONCLUSIOAN}

The findings of the present study provide a substantial discovery in thetrading and service, construction and properties industry that listed on Main Market of Bursa Malaysiafor the relationshipbetween board size and CEO duality on corporate social responsibility (CSR) in Malaysian listed companies. Generally, the role of board size suggest a significant and positive relation- 
ship with CSR disclosure. While CEO duality on CSR disclosure indicate a negative relationship.Thus, authorities shouldconsider more analysis on this link and its contributions and possibleimprovements to CSR among Malaysian listed companies in the trading and service, construction and properties industry. CSR reporting have become a mandatory disclosure from voluntary disclosure. For as Malaysia, the government make it compulsory to publicly listed companies to disclose the CSR information in their annual reports. When companies focus on CSR they are not only driven their companies to be profitable leaders but also has positive effect from socially responsibility perspective. In that, that The new improvement done by the current study is that it focuses on the link of corporate governance characteristics, earning management to CSR disclosure by moderating internal audit function. The sample size was 125 companies under trading and services, construction and properties industry. These companies selected as control variable for some a few reasons. First, both industries showed have a positive growth in the Malaysian GDP 2016 which probably earnings management takes place in the companies. In addition, construction and properties tend to be environmental intensive since they might give bigger impact on the nature. So corporations be likely to disclose more on environmentally friendly. Further, these industries tended to create more waste compared finance and banking. The possible waste emanation to air, water and land can lead to crucial environmental problem. The current study also revealed the importance of getting new trends in corporate governance field via taking into account testing the link between corporate governance mechanisms and financial Industry from Islamic perspective in Asia. The current study strongly recommended the future researchers to focus on both corporate governance and financial Industry from Islamic perspective as a new trend might be positively added to the field of corporate governance or to be linked with it due to the significance for these two fields.

\section{ACKNOWLEDGMENT}

The authors wish to acknowledge Eny Maryanti from Universitas Muhammadiyah Sidoarjo, Indonesia for her assistance in publishing this paper, her help is greatly appreciated.

\section{REFERENCES}

Abushammala, S. N., Alabdullah, T. T. Y., and Ahmed, E. R. (2015). Causal Relationship between Market Growth and Economic Growth. Comparison Study. European Journal of Business and Management 7.

Ahmad, N. B. J., Rashid, Afzalur, and Gow, J. (2017). Board Independence and Corporate Social Responsibility (Csr) Reporting In Malaysia. Australasian Accounting, Business and Finance Journal 11, 61-85.

Ahmed, E. R. (2010). Factors Influencing the Involvement in Shubuhat Activities: The Case of Shari 'ah-Complaint Companies in Bursa Malaysia. vol. June 2010, In IBAF International Conference on Islamic banking \& finance in Kuala Lampur., ed. and others.

Ahmed, E. R., Aiffin, K. H. B., Alabdullah, T. T. Y., and Zuqebah, A. (2016). Zakat and Accounting Valuation Model. Journal of Reviews on Global Economics 5, 16-24.

Ahmed, E. R., Alabdullah, T. T. Y., Amran, A., and Yahya, S. B. (2018a). Indebtedness Theory and Shariah Boards: A Theoretical Approach. Global Business \& Management Research 1.

Ahmed, E. R., Alabdullah, T. Y., Islam, M. A., and M.Asmar (2014a). Sukuk Legitimacy: A New Measurement Based on Content Analysis. In 16th Malaysian Finance Association Conference in Sasana Kijang Central Bank of Malaysia, Kuala Lumpur, (Kuala Lumpur).

Ahmed, E. R., Amran, A., and Islam, M. A. (2018b). Sukuk documentation and legitimacy: the role of shariah supervisory board as a moderator. Management 5, 22-40.

Ahmed, E. R., Islam, A., Alabdullah, T. T. Y., and Amran, A
(2019). A Qualitative Analysis on The Determinants of Legitimacy of Sukuk. Journal of Islamic Accounting and Business Research 10.

Ahmed, E. R., Islam, A., Zuqibeh, A., and Alabdullah, T. Y. (2014b). Risks Management in Islamic Financial Instruments. Advances in Environmental Biology 8, 402-406.

Ahmed, E. R., Islam, M. A., and Alabdullah, T. T. Y. (2018c). The moderating role of Shariah supervisory board on sukuk pricing benchmark. International Journal of Excellence in Islamic Banking and Finance 6.

Ahmed, E. R., Islam, M. A., Ariffin, B., Halim, K., and Moniruzzaman, M. (2013a). Contemporary Challenges And Prospects of Sukuk. Journal of Self-Governance \& Management Economics, 1-1.

Ahmed, E. R., Islam, M. A., and Ariffin, K. H. K. (2015). An Empirical Analysis on Legitimacy of Sukuk: An Insight of Malaysian Sukuk. Asian Social Science 11, 84-84.

Ahmed, E. R., Islam, M. A., and Harthy, F. N. (2013b). The Relationship between Shareholders and Shubuhat: A Study on the Islamic Banks in Malaysia. Journal of Asian Scientific Research 3, 538-538.

Ahmed, E. R., Islam, M. A., and .Y.Alabdullah, T. (2014c). Islamic Sukuk: Pricing Mechanism and Rating. Journal of Asian Scientific Research 4, 640-648.

Ahmed, E. R., Yahaya, S., and M.Harashid. (2012). Shubuhat on Matter of Bai'alinah and Tawarruq. . International Journal of Business and Technopreneurship 2, 85-101.

Ahmed, E. R. and Zuqibeh, A. (2013). The Role of Shariah Supervisory Board in the Reviewing and Supervision on Takaful (Islamic Insurance). Insurance and Takaful Journal. INTAJ. 
Aitsidhoum, A. and Serra, T. (2018). Corporate sustainable development. Revisiting the relationship between corporate social responsibility dimensions. Sustainable Development 26, 365-378.

Akhtaruddin, M., Hossain, M. A., Hossain, M., and Yao, L. (2009). Corporate Governance and Voluntary Disclosure in Corporate Annual Reports of Malaysian Listed Firms. Journal of Applied Management Accounting Research.

Alabdullah, T. T. Y. (2016).

Alabdullah, T. T. Y. (2016a). Corporate Governance from The Perspective of The Past and The Present and The Need to Fill an International Gap. Risk Governance \& Control: Financial Markets \& Institutions 6.

Alabdullah, T. T. Y. (2016b). The Performance of Companies and The Board's Characteristics From the New Perspective of Manipulation Avoidance. Corporate Ownership \& Control 13, 279-286.

Alabdullah, T. T. Y. (2016c). Are Board Size and Ownership Structure Beneficial in Emerging Markets' Firms? Evidence From Jordan. International Journal of Management \& Information Systems (IJMIS) 20, 87-94.

Alabdullah, T. T. Y. (2016d). Corporate governance from the perspective of the past and the present and the need to fill an international gap. Risk Governance and Control: Financial Markets and Institutions 6, 96-101.

Alabdullah, T. T. Y. (2018a). The relationship between ownership structure and firm financial performance: Evidence from Jordan. Benchmarking: An International Journal 25, 319-333.

Alabdullah, T. T. Y. (2018b). The relationship between ownership structure and firm financial performance: Evidence from Jordan. Benchmarking: An International Journal 25, 319-333.

Alabdullah, T. T. Y. and Ahmed, E. R. (2018). Corporate Governance: To What Extent it is important in the Arab Countries?, . International Journal of Science and Research, Vol.7(11).

Alabdullah, T. T. Y., Alfadhl, M. M. A., Yahya, S., and Rabi, A M. A. (2014a). The Role of Forensic Accounting in Reducing Financial Corruption: A Study in Iraq. International Journal of Business and Management 9, 26-26.

Alabdullah, T. T. Y., Nor, M. I., and E.Ries (2018). The Determination of Firm Performance in Emerging Nations: Do Board Size and Firm Size Matter. Management 5, 57-66.

Alabdullah, T. T. Y., Yahya, S., Nor, M. I., and Majeed, F. Q. (2016). An Investigation of Corporate Governance From a New Perspective: Examining The Financial Performance of Companies and The Impact of Executive Turnover. Corporate Board: Role, Duties \& Composition 12, 53-67.

Alabdullah, T. T. Y., Yahya, S., and T.Ramayah (2014b). Corporate Governance Mechanisms and Jordanian Companies' Financial Performance. Asian Social Science 10, 247 247.

Alabdullah, T. Y., SofriYahya, and Thurasamy, R. (2014c) Corporate Governance Development: New or Old Concept? European Journal of Business and Management 6, 312-315.

Alfadhl, M. M. A. F. and Alabdullah, T. T. Y. (2013). Determinants of the Managerial Behavior of Agency Cost and Its Influential Extent on Performance: A Study in Iraq. International Journal of Humanities and Social Science, 3-3.

Ararat, M., Black, B. S., and Yurtoglu, B. B. (2017). The effect of corporate governance on firm value and profitability: Time-series evidence from Turkey.

Arora, A. and C.Sharma (2016). Corporate governance and firm performance in developing countries: evidence from India. Corporate governance 16, 420-436.

Chen, X. (2017). Improved Corporate Governance and Chinese Seasoned Equity Offering Announcement Effects. Accounting \& Finance 57, 401-428.

Cheng, E. C. and Courtenay, S. M. (2006). Board composition, regulatory regime and voluntary disclosure. The international journal of accounting. The International Journal of
Accounting 41, 262-289.

Cuñat, V., Gine, M., and Guadalupe, M. (2012). The vote is cast: The effect of corporate governance on shareholder value. The journal of finance. The Journal of Finance 67, 1943-1977.

Dewji, H. and Miller, S. (2013). Assessing the components of effective corporate governance. Strategic Management Review 7, 47-63.

Ehikioya, B. I. (2009). Corporate governance structure and firm performance in developing economies: evidence from Nigeria. Corporate Governance 9, 231-243.

Fan, J. P. H. and Wong, T. J. (2001). Do external auditors perform a corporate governance role in emerging markets? Evidence from East Asia. EFA 2001 Barcelona Meetings. 3rd Annual Fin. Mkt. Dev. Conference, Hong Kong. Available at SSRN.

Fan, P. S. (2004). Review of Literature \& Empirical Research on Corporate Governance'. Monetary Authority of Singapore (MAS) Staff Paper. In The Monetary Authority of Singapore.

Forker, J. J. (1992). Corporate Governance and Disclosure Quality. Accounting and Business research.

Gul, F. A. and Leung, S. (2004). Board Leadership, Outside Directors' Expertise and Voluntary Corporate Disclosures. Journal of Accounting and Public Policy 23, 351-379.

Gulzar, M. A. (2011). Corporate governance characteristics and earnings management: Empirical evidence from Chinese listed firms. International Journal of Accounting and Financial Reporting 1, 133-133.

Haniffa, R. M. and Cooke, T. E. (2005). The Impact of Culture and Governance on Corporate Social Reporting. Journal of Accounting and Public Policy 24, 391-430.

I.Dzingai and Fakoya, M. (2017). Effect of Corporate Governance Structure on the Financial Performance of Johannesburg Stock Exchange (JSE)-Listed Mining Firms. . Sustainability $9,867$.

Jensen, M. C. (1993). The Modern Industrial Revolution, Exit, and The Failure of Internal Control Systems. The Journal of Finance 48, 831-880.

Jensen, M. C. and Meckling, W. H. (1976). Theory of The Firm: Managerial Behavior, Agency Costs and Ownership Structure. Journal of Financial Economics 3, 305-360.

Jiraporn, P., Jiraporn, N., Boeprasert, A., and Chang, K. (2014). Does corporate social responsibility (CSR) improve credit ratings? Evidence From Geographic Identification. Financial Management 43, 505-531.

Jizi, M. I., A.Salama, Dixon, R., and Stratling, R. (2014). Corporate Governance and Corporate Social Responsibility Disclosure: Evidence From The US Banking Sector. Journal of Business Ethics 125, 601-615.

Lee, J. W., Kim, Y. M., and Kim, Y. E. (2018). Antecedents of Adopting Corporate Environmental Responsibility and Green Practices. Journal of Business Ethics 148, 397-409.

Lenssen, G., Blagov, Y., Bevan, D., Peters, S., Miller, M., S.Kusyk, et al. (2011). How relevant is corporate governance and corporate social responsibility in emerging markets. Corporate Governance: The international journal of business in society.

Lipton, M. and lorsch, J. W. (1992). A modest proposal for improved corporate governance. The business lawyer. JSTOR 48, 59-77.

Majumder, M. T. H., Akter, A., and Li, X. (2017). Corporate Governance and Corporate Social Disclosures: A MetaAnalytical Review. International Journal of Accounting and Information Management 25.

Mak, Y. T. and Roush, M. L. (2000). Factors Affecting the Characteristics of Boards of Directors: An Empirical Study of New Zealand Initial Public Offering Firms. Journal of Business Research 47.

Manab, N. A., Kassim, I., and R.Hussin, M. (2010). Enterprisewide risk management (EWRM) practices: Between corporate governance compliance and value. International Review of Business Research Papers 6, 239-252. 
Mang'unyi, E. E. (2011). Ownership Structure and Corporate Governance and Its Effects on Performance: A Case of Selected Banks in Kenya. International journal of business administration 2 .

M.Halme and .Huse, M. (1997). The Influence of Corporate Governance, Industry and Country Factors on Environmental Reporting. Scandinavian Journal of Management 13, 137-157.

Michelon, G. and Parbonetti, A. (2012). The Effect of corporate governance on sustainability disclosure. Journal of Management and Governance 16, 1-33.

Narwal, K. and Jindal, S. (2015). The impact of corporate governance on the profitability: An empirical study of Indian textile industry. International Journal of Research in Management, Science \& Technology 3, 81-85.

Palaniappan, G. (2017). Determinants of corporate financial performance relating to board characteristics of corporate governance in Indian manufacturing industry: An empirical study. . European Journal of Management and Business Economics. 26(1), 67-85.

Peni, E. and Vähämaa, S. (2012). Did good corporate governance improve bank performance during the financia crisis? Journal of Financial Services Research 41, 19-35.

Rao, K. K., Tilt, C. A., and Lester, L. H. (2012). Corporate Governance and Environmental Reporting: an Australian Study. Corporate Governance: The International Journa of Business in Society. Emerald 12, 143-163.

Sadou, A. et al. (2017). Corporate Social Responsibility Disclosures in Malaysia: Evidence From Large Companies. Social Responsibility Journal 13.

Said, R., Yuserrie, H. Z., and Hasnah, H. (2009). The Relation- ship Between Corporate Social Responsibility Disclosure and Corporate Governance Characteristics in Malaysia. Social Responsibility Journal 5, 212-226.

Tai, F. M. and Chuang, S. H. (2014). Corporate social responsibility $6,117$.

Uwalomwa, U. and Ajibolade, S. (2013). Effects of Corporate Governance on Corporate Social and Environmental Disclosure Among Listed Firms in Nigeria. European Journal of Business and Social Sciences 2, 76-92.

Yuen, C. Y. D., Liu, M., Zhang, X., and C.Lu (2008). A Case Study of Voluntary Disclosure by Chinese Enterprises Article (PDF Available) · April 2008with256 Reads.

Zahra, S. A. and Pearce, J. A. (1989). Boards of Directors and Corporate Financial Performance: A Review and Integrative Model. Journal of Management 15.

Conflict of Interest Statement: The authors declare that the research was conducted in the absence of any commercial or financial relationships that could be construed as a potential conflict of interest.

Copyright (ㄷ) 2019, and. This is an open-access article distributed under the terms of the Creative Commons Attribution License (CC BY). The use, distribution or reproduction in other forums is permitted, provided the original author(s) and the copyright owner(s) are credited and that the original publication in this journal is cited, in accordance with accepted academic practice. No use, distribution or reproduction is permitted which does not comply with these terms. 


\section{LIST OF TABLES}

1 Measurement of Independent Variables . . . . . . . . . . . . . . . 131

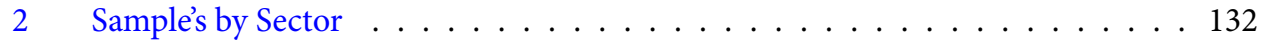

3 Frequency Table for Board Size . . . . . . . . . . . . . . . 133

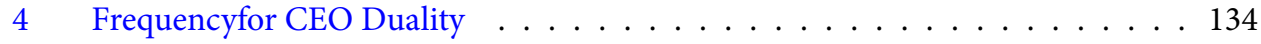

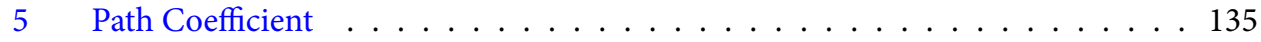


TABLE 1 | Measurement of Independent Variables

Indepen-

dent

Variables

Board Size

"BSIZ": Total Number of Directors in the board.(Said et al. (2009)

CEO Duality "CEO DUALITY": CEO of company holds the chairman position as well in the board. "1" score given if the CEO holds the chairman position, and "O" score given if otherwise Said et al. (2009) 
TABLE 2 | Sample's by Sector

\begin{tabular}{llll} 
Sector & Number of Company & Number of Sample & Percentage (\%) \\
Trading and Services & 212 & 45 & 36 \\
Construction & 46 & 34 & 27 \\
Property & 94 & 46 & 37 \\
Total & 352 & 125 & 100 \\
\hline
\end{tabular}


TABLE 3 | Frequency Table for Board Size

\begin{tabular}{lll}
\hline Number of Director & Frequency & Percent \\
4 & 3 & 2.4 \\
5 & 8 & 6.4 \\
6 & 17 & 13.6 \\
7 & 23 & 18.4 \\
8 & 25 & 20.0 \\
9 & 22 & 17.6 \\
10 & 9 & 7.2 \\
11 & 6 & 4.8 \\
12 & 6 & 4.8 \\
13 & 2 & 1.6 \\
14 & 3 & 2.4 \\
15 & 1 & 0.8 \\
Total & 125 & 100 \\
\hline
\end{tabular}


TABLE 4 | Frequencyfor CEO Duality

\begin{tabular}{lll}
\hline CEO Duality & Frequency & Percent \\
No & 116 & 92.8 \\
Yes & 9 & 7.2 \\
Total & 125 & 100 \\
\hline
\end{tabular}


TABLE 5 | Path Coefficient

\begin{tabular}{llllll}
\hline Hypothesis & Path & Path Coefficient & Standard Error & T-Value(1 tailed) & Decision \\
H1 & BSIZE ${ }^{\circledR}$ CSRD & 0.148 & 0.089 & 1.667 & Accept \\
H2 & CEO ${ }^{\circledR}$ CSRD & -0.110 & 0.081 & 1.351 & Reject \\
\hline
\end{tabular}

